\title{
PRELIMINARY OBSERVATIONS ON
} THE SO-CALLED HEAPING BEHAVIOUR IN A SEA URCHIN, HEMICENTROTUS PULCHERRIMUS (A. AGASSIZ)

\section{$\operatorname{AUTHOR}(S):$}

Yanagisawa, Yasunobu

\section{CITATION:}

Yanagisawa, Yasunobu. PRELIMINARY OBSERVATIONS ON THE SO-CALLED HEAPING BEHAVIOUR IN A SEA URCHIN, HEMICENTROTUS PULCHERRIMUS (A. AGASSIZ).

PUBLICATIONS OF THE SETO MARINE BIOLOGICAL LABORATORY 1972, 19(6): 431-435

\section{ISSUE DATE:}

1972-03-31

URL:

http://hdl.handle.net/2433/175734

RIGHT: 


\title{
PRELIMINARY OBSERVATIONS ON THE SO-CALLED HEAPING BEHAVIOUR IN A SEA URCHIN, HEMICENTROTUS PULCHERRIMUS (A. AGASSIZ) ${ }^{13}$
}

\author{
YASUNOBU YANAGISAWA
}

Seto Marine Biological Laboratory

Many echinoids are known to catch shell fragments, algal pieces and pebbles. This behaviour has been called the heaping or covering behaviour and observed on the coast of the vicinity of Seto most prominently in such tropical species as Mespilia globulus (Linnaeus), Toxopneustes pileolus (Lamarak), Tripneustes gratilla (Linnaeus). This behaviour is seen, though much less remarkably, in Hemicentrotus pulcherrimus (A. Agassiz) endemic to Japan and usually living in rocky crevices or under boulders of different sizes at shallow subtidal levels. I have noticed, however, that the behaviour is largely pronounced when this sea urchin is placed exposedly, together with some material for heaping, in the tank in the laboratory. To see this behaviour in detail in this sea urchin, some preliminary experiments were carried out from December 1971 to February 1972.

I wish to express my sincere thanks to Dr. T. TокіокA of the Seto Marine Biological Laboratory for his critical reading of the manuscript.

\section{Material, Methods, and Results}

About forty individuals of Hemicentrotus were collected from a subtidal rocky crevice on the northwestern coast of the Seto Marine Biological Laboratory and kept alive in the laboratory in a tank with running sea-water to be experimented with. Experiment $A$ : It is observed that any fragments of shell, alga, pebble, etc., which have come in contact with the tube feet of this sea urchin, are held on the surface of the urchin. These fragments are then carried either to the mouth or to the aboral or peripheral side of the urchin. Algal fragments brought to the mouth will be fed by the sea urchin. However, it seemed that the sea urchin had a tendency to carry algal fragments to the aboral or peripheral side when the room was light, but to carry them to the mouth to feed when the room was dark. Then to confirm the positive relation between the reactions and the light conditions, some preliminary experiments were designed as follows. Prior to experiments, Hemicentrotus were all kept in a tank without feeding for more than two weeks.

1) Contributions from the Seto Marine Biological Laboratory, No. 563.

Publ. Seto Mar. Biol. Lab., XIX (6), 431-435, 1972. (Article 29) 
Two or three urchins were placed in a tray, $35 \mathrm{~cm} \times 26 \mathrm{~cm}$ in extent and $6 \mathrm{~cm}$ deep and illuminated at ca. 500 Lux by a fluorescent lamp. Then a piece of Sargassum patens G. Agardh, roughly as long as the test diameter of the sea urchin, was given to each urchin in such a short distance that the urchin could reach it by slight movement. Movement of the algal piece held by tube feet and spines was traced for ten minutes and then its position was recorded. The same experiment was repeated on the same and other urchins. In a similar way, experiments were carried out in the dark condition under the illumination of about 1 Lux. The results of these experiments carried out on December 17 and 18, 1971 are shown in Tables 1 (a) and (b), respectively. The test diameter of sea urchins experimented with ranged from 8 to $33 \mathrm{~mm}$,

Table 1. Number of urchins, carried algal pieces to the mouth, or to the aboral or peripheral side in the starved state.

\begin{tabular}{|c|c|c|c|c|c|}
\hline a) & & $\begin{array}{l}\text { Number of } \\
\text { urchins } \\
\text { experimented } \\
\text { with }\end{array}$ & $\begin{array}{l}\text { Number of } \\
\text { urchins carried } \\
\text { pieces to mouth }\end{array}$ & $\begin{array}{l}\text { Number of } \\
\text { urchins carried } \\
\text { pieces to aboral } \\
\text { side }\end{array}$ & $\begin{array}{l}\text { Number of } \\
\text { urchins showing } \\
\text { no definite } \\
\text { reaction to } \\
\text { pieces }\end{array}$ \\
\hline \multirow{2}{*}{ Adult } & lighted & 84 & 40 & 43 & 1 \\
\hline & dark & 36 & 34 & 2 & 0 \\
\hline \multirow{2}{*}{ Young } & lighted & 42 & 32 & 10 & 0 \\
\hline & dark & 18 & 18 & 0 & 0 \\
\hline
\end{tabular}

\begin{tabular}{|c|c|c|c|c|c|}
\hline \multicolumn{2}{|l|}{ (b) } & $\begin{array}{l}\text { Number of } \\
\text { urchins } \\
\text { experimented } \\
\text { with }\end{array}$ & $\begin{array}{l}\text { Number of } \\
\text { urchins carried } \\
\text { pieces to mouth }\end{array}$ & $\begin{array}{l}\text { Number of } \\
\text { urchins carried } \\
\text { pieces to aboral } \\
\text { side }\end{array}$ & $\begin{array}{l}\text { Number of } \\
\text { urchins showing } \\
\text { no definite } \\
\text { reaction to } \\
\text { pieces }\end{array}$ \\
\hline \multirow{2}{*}{ Adult } & lighted & 52 & 12 & 40 & 0 \\
\hline & dark & 32 & 27 & 5 & 0 \\
\hline \multirow{2}{*}{ Young } & lighted & 26 & 11 & 15 & 0 \\
\hline & dark & 16 & 16 & 0 & 0 \\
\hline
\end{tabular}

Table 2. Number of urchins, carried algal pieces to the mouth, or to the aboral or peripheral side in the well-fed state.

\begin{tabular}{|c|c|c|c|c|c|}
\hline & & $\begin{array}{l}\text { Number of } \\
\text { urchins } \\
\text { experimented } \\
\text { with }\end{array}$ & $\begin{array}{l}\text { Number of } \\
\text { urchins carried } \\
\text { pieces to mouth }\end{array}$ & $\begin{array}{l}\text { Number of } \\
\text { urchins carried } \\
\text { pieces to aboral } \\
\text { side }\end{array}$ & $\begin{array}{l}\text { Number of } \\
\text { urchins showing } \\
\text { no definite } \\
\text { reaction to } \\
\text { pieces }\end{array}$ \\
\hline \multirow{2}{*}{ Adult } & lighted & 32 & 5 & 22 & 5 \\
\hline & dark & 32 & 12 & 14 & 6 \\
\hline
\end{tabular}


specimens with the test diameter 8 to $13 \mathrm{~mm}$ were regarded as O-year individuals and noted as young, while those larger than $18 \mathrm{~mm}$ were regarded as over 1-year individuals and noted as adult in tables. The water temperature fluctuated from $15.2^{\circ} \mathrm{C}$ to $16.6^{\circ} \mathrm{C}$ during experiments. The control experiments were made on the well-fed individuals of the sea urchin at the water temperature of $13^{\circ} \mathrm{C}$, the results are given in Table 2.

In the lighted condition, more than half of starved adult urchins carried an algal piece to the aboral or peripheral side, while the others carried it to the mouth to eat. On the contrary, in the dark condition, the larger part of starved adult urchins carried the piece to the mouth to eat. Starved young urchins showed roughly the same tendency as in adult urchins, but the rate of individuals which transported the algal piece to the mouth to eat in the lighted condition was evidently larger than in adults, though in dark, all starved young urchins fed the algal piece. Wellfed urchins seemed somewhat inactive as about twenty percent of individuals experimented with did not hold an algal piece after they touched it by tube feet. Further the rate of individuals which carried the piece to the aboral or peripheral side was clealy larger than in starved urchins in either of lighted and dark conditions. These results seem to show that Hemicentrotus generally carry algal pieces caught by tube feet to the aboral or peripheral side in the lighted condition, but to the mouth to eat in the dark condition and that these reactions are seen distinctly in starved adults, but the reaction in the lighted condition becomes much less distinct in young and the reaction to carry pieces to the mouth becomes much less active in well-fed adults in either of lighted and dark conditions.

Experiment $B$ : The tube feet of sea urcins show a positive reaction to contact, namely they have the tactile sensibility. But it is little known whether they have an ability to distinguish the nature of different materials from one another, caught on the aboral side. For the purpose to know this, an algal piece and a shell fragment, both about one fifth as large as the size of the aboral surface, were put on the aboral side at a time, and both materials were traced for ten minutes in both the lighted (ca. 600 Lux) and dark (ca. 1 Lux) conditions and on both the starved and well-fed adults. The results of observations are shown in Table 3 .

Table 3. Number of sea urchins, carried preferentially algal pieces to the mouth.

\begin{tabular}{|c|c|c|c|c|c|c|}
\hline & & $\begin{array}{l}\text { Number of } \\
\text { urchins } \\
\text { experimented } \\
\text { with }\end{array}$ & $\begin{array}{l}\text { Number of } \\
\text { urchins carri- } \\
\text { ed algal and } \\
\text { shell to } \\
\text { mouth }\end{array}$ & $\begin{array}{l}\text { Number of } \\
\text { urchins } \\
\text { carried algal } \\
\text { pieces to } \\
\text { mouth }\end{array}$ & $\begin{array}{l}\text { Number of } \\
\text { urchins } \\
\text { carried shell } \\
\text { pieces to } \\
\text { mouth }\end{array}$ & $\begin{array}{l}\text { Number of } \\
\text { urchins } \\
\text { retained } \\
\text { algal and } \\
\text { shell pieces on } \\
\text { aboral side }\end{array}$ \\
\hline \multirow{2}{*}{$\begin{array}{l}\text { Starved } \\
\text { urchins }\end{array}$} & lighted & 17 & 0 & 11 & 0 & 6 \\
\hline & dark & 32 & 0 & 29 & 0 & 3 \\
\hline $\begin{array}{l}\text { Well-fed } \\
\text { urchins }\end{array}$ & dark & 16 & 0 & 2 & 0 & 14 \\
\hline
\end{tabular}


It was found that the larger part of sea urchins carried the algal piece to the mouth to eat, but leaving the shell fragment on the aboral or peripheral side, while the rest retained both the algal and shell fragments on the aboral or peripheral side. In this experiment, no urchins carried the shell fragment to the mouth. This observation seems to suggest that the sea urchin is able to distinguish the algal piece from the shell fragment and capable of selecting algae to eat.

Experiment $C$ : Lastly, only a single shell fragment was put on the aboral side of the starved or well-fed adult urchin in the tray and the fragment was traced for ten minutes in both the lighted (ca.600 Lux) and dark (ca. 1 Lux) conditions. The results are shown in Table 4.

Table 4. Number of sea urchins, carried shell fragments to the mouth.

\begin{tabular}{|c|c|c|c|c|}
\hline & & $\begin{array}{l}\text { Number of } \\
\text { urchins } \\
\text { experimented } \\
\text { with }\end{array}$ & $\begin{array}{l}\text { Number of } \\
\text { urchins carried } \\
\text { shell fragments } \\
\text { to mouth }\end{array}$ & $\begin{array}{l}\text { Number of } \\
\text { urchins retained } \\
\text { shell fragments } \\
\text { on aboral side }\end{array}$ \\
\hline \multirow{2}{*}{$\begin{array}{l}\text { Starved } \\
\text { urchins }\end{array}$} & lighted & 36 & 19 & 17 \\
\hline & dark & 24 & 11 & 13 \\
\hline \multirow{2}{*}{$\begin{array}{l}\text { Well-fed } \\
\text { urchins }\end{array}$} & lighted & 24 & 0 & 24 \\
\hline & dark & 16 & 2 & 14 \\
\hline
\end{tabular}

Though the well-fed urchins scarcely carried the fragment to the mouth, about a half of starved urchins carried it to the mouth in both the lighted and dark conditions and some of them seemed even to try to graze it. It may thus be imagined that every material caught on the test surface may be carried to the mouth to eat, especially in a starved state. It is clear that this can not be concluded on the present single observation. Further, I wonder why starved urchins left the shell fragment on the aboral side when it was put there together with algae and why about a half of them carried it to the mouth when it was put there alone.

\section{Considerations}

Hemicentrotus pulcherrimus inhabits mainly rocky crevices or under boulders at shallow subtidal levels. It is very probable that in addition to grazing the growing algae, drifting algal debris form a significant part of food for this sea urchin. From a point of view of obtaining food, the positive tactile response and further holding of drifting algal debris around the body with tube feet and spines must be very significant for sea urchins. In the laboratory, it was made clear that the tube feet of this sea urchin responded positively to contact and retained the caught algal pieces mainly as shade in the light but took them as food in dark. These reactions seem to conform to nocturnal feeding of this sea urchin. It was further observed that algal pieces heaped on the aboral side in the lighted condition were ultimately carried to the mouth to 
eat within several hours.

EBERT (1968) suggested that algal pieces held by spines and tube feet of Strongylocentrotus purpuratus were utilized for food. Dix (1970) also reported on his diving observations that all substances held on the body surface as cover in Evechinus chloroticus were also found to be utilized for food. On the other hand, the heaping behaviour have been evaluated by Mortensen (1927), Millot (1956), Nichols (1964) and Yoshida (1966) to protect urchins from light or to camouflage them. The behaviours observed in Hemicentrotus seem evidently to show two sides of their effects, one as a significant mechanism of food collection and the other as formation of shade to the light or of camouflage. The observation that algal pieces held as shade on the aboral or peripheral side are ultimately utilized for food might show that the effect of behaviours in feeding is more essential.

\section{REFERENCES}

Dix, T. G. 1970. Govering response of the echinoid Evechinus chloroticus (VAL.) Pacific Science, vol. 24, no. 2, pp. 187-194.

Ebert, T. A. 1968. Growth rates of the sea urchin Strongylocentrotus purpuratus related to food availability and spine abrasion. Ecology, vol. 49, no. 6, pp. 1075-1091.

Mrllot, N. 1956. The covering reaction of sea urchins. I. A preliminary account of covering in the tropical echinoid Lytechinus variegatus (LAMARcK), and its relation to light. Journal of Experimental Biology, vol. 33, pp. 508-523.

Mortensen, T. 1927. Handbook of the Echinoderms of the British Isles. Oxford Univ. Press, $471 \mathrm{pp}$.

Nichols, D. 1964. Echinoderms: experimental and ecological. Oceanography and Marine Biology, an Annual Review, vol. 2, pp. 393-423.

Yoshida, M. 1966. Photosensitivity. In: R. A. Boolootian, ed., Physiology of Echinodermata, pp. 435-464. John Wiley and Sons, New York. 